\title{
Who matters to universities? A stakeholder perspective on humanities, arts and social sciences valorisation
}

\author{
Paul Benneworth $\cdot$ Ben W. Jongbloed
}

Published online: 31 July 2009

(C) The Author(s) 2009. This article is published with open access at Springerlink.com

\begin{abstract}
Valorisation is at the centre of many debates on the future of academic research. But valorisation has largely become narrowly understood in terms of universities' economic contributions through patenting, licensing, spin-off formation and technology transfer. This emergent restrictive definition of universities' societal impacts is a worrying development, overlooking the potential of universities' knowledge in the Humanities, Arts and Social Sciences (HASS). Our hypothesis is that HASS disciplines' disadvantage compared to the hard sciences (lesser policy attention and funding for commercialisation) arises because HASS stakeholders are not sufficiently salient as stakeholders to universities. Using case studies of three policy experiments, we argue that universities' responsiveness to stakeholders does not evolve simply and functionally but in response to the networks of relationships in which they are situated. This has important implications for how stakeholder research is used in higher education research, and for the design and implementation of policies to improve universities' societal contributions.
\end{abstract}

Keywords Universities - Knowledge transfer · Knowledge exchange · Universities' societal contribution · Social compact · Stakeholder theory ·

Knowledge transfer policy

\section{Introduction}

Valorisation is at the centre of many debates on the future of academic research. Valorisation encompasses all activities that contribute to ensuring that the outcomes of scientific knowledge add value beyond the scientific domain. It includes making the results from academic research available or more easily accessible in order to increase the chances of

P. Benneworth $(\bowtie) \cdot$ B. W. Jongbloed

Center for Higher Education Policy Studies, University of Twente,

Enschede, The Netherlands

e-mail: P.benneworth@utwente.nl

B. W. Jongbloed

e-mail: B.w.a.jongbloed@utwente.nl 
others-outside academia-making use of it, as well as the co-production of knowledge with non-academic groups (cf. Bryson 2000). Valorisation is therefore broader than 'commercialisation', motivated by commercial profit in the context of an increasingly marketised academy (Slaughter and Leslie 1997, 2001; Bridgman and Wilmott 2007). However, there is also an active tension between valorisation and commercialisation, with valorisation often framed as commercialisation, potentially narrowly understood in terms of universities' economic contributions, potentially overshadowing broader societal contributions (OECD 2007).

The popularisation of this more limited view of valorisation reflects three underpinning realities. Firstly, valorisation is framed by the rise of the hegemonic discourse of academic capitalism, increasing the emphasis of private benefit over public, viewing academics as capitalists in the public sector (Slaughter and Leslie 2001; May 2007). Barnett argues (2003) that the ideology of the entrepreneurial university has been so successful because of its simplicity and clarity, which in turn shapes the other two drivers. Secondly, models for valorisation have been driven by successes in the physical and life sciences which are not necessarily immediately transferable to humanities and social sciences (AHRC 2006). Thirdly, commercial pressures have encouraged simple responses with fast returns on investment over the longer term application of knowledge to more complex societal problems (Barnett 2003; Greenwood 2007). Compared to 'hard' sciences, humanities and social sciences' (HASS) social benefits and services are more diffuse and less easily enumerated and capitalized. Likewise, their 'clients' or beneficiaries often are public bodies, non-profit organisations, and other community groups with lower purchasing power (AWT 2007).

This limited view of valorisation has proven influential with policy-makers. A recent report by the Dutch Advisory Council for Science and Technology Policy (AWT) concerning HASS valorisation argues for a broader view, stressing universities' wider societal, cultural and democratic impacts alongside the purely economic (AWT 2007). Universities are important drivers of innovation in many domains (such as education, politics, health care, and law). However, policy-makers' capacities to exploit these wider benefits have considerably lagged their capacities to effectively promote commercialisation in disciplines like engineering, natural sciences, information technology and life sciences. The Dutch Hydrocarbon Funds, the UK's Knowledge Transfer Partnership Programme and the Swedish VINNVÄXT programmes have been largely focused on university/business interactions, rather than with university/society relationships more generally. Only recently in the Netherlands has the concept of "Leading Social Research Institutes" (Maatschappelijke Topinstituten) been launched, stressing the importance of HASS to national innovation systems. ${ }^{1}$

This affects wider developments in the social contract between higher education and society through which universities receive public funding and other privileges (Barnett 2000; Neave 2006). The discourse on the role of the university (Rothblatt 1997; Barnett 1990) has shifted since the post-war years (Geiger 1993) towards an increasingly marketlike stance (Slaughter and Leslie 1997). The social contract is being redefined, emphasising university's responsibilities towards a broader range of stakeholders than is traditional, including government, students, and the academic community ('peers'). In particular,

\footnotetext{
1 The name leading Social Research Institute reflects the idea that this type of institute is to be oriented on social themes and social innovation, instead of solely on technological innovation. In 2005, the Minister of Education (through the Dutch research council, NWO) made funds available to support three research initiatives (on, respectively Pensions \& Ageing, Urban Innovation, and International law).
} 
emphasising commercialisation substantially changed the relationship between universities and one significant stakeholder group (NCIHE 1997; Neave 2006), namely business.

The more restrictive view of valorisation hindering HASS commercialisation could be re-conceptualised as a failure for HASS users to have become key university "stakeholders". In this paper, our key research question is whether a stakeholder approach provides insights which aid conceptualisation of the problem, but also the development of policies which improve university HASS valorisation. We firstly develop a working hypothesis drawing on stakeholder theory, and explore that with reference to three different policy attempts to improve HASS valorisation by giving external stakeholders capacity to influence universities' internal agendas. We argue that HASS valorisation is shaped by drivers on multiple levels, and real impacts evolve in response to simultaneous changes across different scales. This suggests successful HASS valorisation requires both a reframing of the value placed on HASS knowledges by societal stakeholders as well as the development of particular instruments where HASS knowledges are valorised.

\section{University decision-making and stakeholder theory}

As recipients of public funding, universities must account for their activities and achievements to government and wider society. Increasingly they must demonstrate wider benefits arising from their publicly-funded research in line with 'value for money' requirements (e.g. HEFCE 2007). Universities, like other sectors that perform public tasks (Reed and Stanley 2005) are transforming into something similar to social enterprises, linking their production of goods and services to a social mission (SEC 2003). Conventional businesses distribute their profit among shareholders: in social enterprises surpluses are reinvested in the organisation to promote those social aims. The "social dividend" therefore comes through the delivery of improved public goods to stakeholders.

Stakeholders are actors-organizations, agencies, clubs, groups or individuals-who may gain or lose from an organization's activities (Ackoff 1981; Allen 1988)—with an interest ('stake') in the organization's performance. Stakeholders are not solely passive recipients of general benefits; they may demand a more active voice in the organisation's running to improve the value of their share and their benefits. Universities' 'stakeholders' include those potentially positioned to benefit from universities' social impacts (Freeman 1984). As universities' wider social aims have evolved, new classes of university stakeholder have emerged. Allen (1988) argues that universities have long-if implicitlypioneered the use of stakeholder management—both internally and externally—as a way of handling their ambiguous purposes, to suppress open conflict between different constituencies (Cohen and March 1974; Baumunt 1997).

Identifying stakeholders in universities' social missions

University success has always depended on capacity to secure resources to achieve their core missions (Ernste 2007). An important element of this is the creation of 'useful knowledge' embedded in people, technologies, books and networks (Spaapen et al. 2007; Marginson 2007). The value of that knowledge is defined by universities' key stakeholders through terms such as its quality, utility and relevance. Freeman's definition of stakeholder (1984, p. 46) is very broad, 'any group or individual who can affect or is affected by the achievement of the organization's objectives'. Universities' main stakeholders therefore include the international scientific community, industry, politics, the public sector and the 
Table 1 Stakeholder categories and constitutive groups

\begin{tabular}{|c|c|}
\hline Stakeholder category & Constitutive groups, communities \\
\hline Governing entities & $\begin{array}{l}\text { State \& federal government; governing board; board of trustees, buffer } \\
\text { organisations; sponsoring religious organisations }\end{array}$ \\
\hline Administration & President (vice-chancellor); senior administrators \\
\hline Employees & Faculty; administrative staff; support staff \\
\hline Clienteles & $\begin{array}{l}\text { Students; parents/spouses; tuition reimbursement providers; service partners; } \\
\text { employers; field placement sites... }\end{array}$ \\
\hline Suppliers & $\begin{array}{l}\text { Secondary education providers; alumni; other colleges and universities; food } \\
\text { purveyors; insurance companies; utilities; contracted services }\end{array}$ \\
\hline Competitors & $\begin{array}{l}\text { Direct: private and public providers of post-secondary education } \\
\text { Potential: distance providers; new ventures } \\
\text { Substitutes: employer-sponsored training programmes }\end{array}$ \\
\hline Donors & $\begin{array}{l}\text { Individuals (includes trustees, friends, parents, alumni, employees, industry, } \\
\text { research councils, foundations, ...) }\end{array}$ \\
\hline Communities & $\begin{array}{l}\text { Neighbours; school systems; social services; chambers of commerce; special } \\
\text { interest groups... }\end{array}$ \\
\hline $\begin{array}{l}\text { Government } \\
\text { regulators }\end{array}$ & $\begin{array}{l}\text { Ministry of Education; buffer organisations; state \& federal financial aid agencies; } \\
\text { research councils; federal research support; tax authorities; social security; Patent } \\
\text { Office }\end{array}$ \\
\hline $\begin{array}{l}\text { Non-governmental } \\
\text { regulators }\end{array}$ & $\begin{array}{l}\text { Foundations; institutional and programmatic accrediting bodies; professional } \\
\text { associations; church sponsors }\end{array}$ \\
\hline $\begin{array}{l}\text { Financial } \\
\text { intermediaries }\end{array}$ & Banks; fund managers; analysts \\
\hline Joint venture partners & Alliances \& consortia; corporate co-sponsors of research and educational services \\
\hline
\end{tabular}

Source: After Burrows (1999)

general public (Jongbloed et al. 2007). Table 1 (adapted from Burrows 1999, p. 9) presents a typical higher education institution (HEI) stakeholder set, exemplifying specific groups within the various categories that could influence its decisions.

As HEI resources become increasingly dependent on market decisions and metric allocations rather than block grants, universities face an increasingly complicated choice of which stakeholders' interests to prioritise and how to reconcile contradictory interests (Slaughter and Leslie 2001; Greenwood 2007). Stakeholder management is a means to that end (Jawahar and McLaughlin 2001), as university stakeholders place demands or conditions on the university in return for their resources. But just as not all company shareholders are equal, some stakeholders' interests are more influential than others (Jongbloed et al. 2007). The identification of the most important stakeholder groups is not straightforward. Stakeholder theory classifies stakeholders according to their relative importance or salience (cf. Mitchell et al. 1997), and allows us to explore the impact of differential salience on influence over universities (Jongbloed and Goedegebuure 2001).

The salience of stakeholders to universities

Understanding stakeholders' influence over universities' decision-making can be done by developing a hierarchy or ranking of influence, based on those characteristics which make an external party significant to the university. Mitchell et al. (1997) distinguished three defining attributes of stakeholders' influence: 
1. The stakeholder's power to influence the organization. A social relationship in which one actor, A, can get another, B, to do something that B would not have otherwise done. For universities, growing pressure from students, parents and legislators to force universities to adopt more cost-conscious operating principles exemplifies this.

2. The legitimacy of the stakeholder's relationship with the organisation. A generalised perception or assumption that the actions of an entity are desirable, proper, or appropriate within some socially constructed system of norms, values, beliefs, definitions. Today, traditional university stakeholders (e.g. students and governments) have been supplemented by, amongst others, local industry, growth coalitions and property developers (cf. Barnett 2003; Slaughter and Leslie 2001).

3. The urgency of the stakeholder's claim on the organisation: the degree to which stakeholder claims call for immediate action. A good example would be the greater emphasis put on research in health and engineering fields on the challenges of ageing and renewable energy, respectively.

Stakeholders' salience can be defined as the degree to which HEIs' leadership prioritises claims over those of other competing interests (Mitchell et al., p. 869). Stakeholder salience is positively related to the cumulative influence of the three attributes perceived to be present. Following Mitchell et al. (1997), we simplify this by classifying on the basis that the more attributes stakeholders hold, the greater their influence on university decision-making processes (see Fig. 1 below). Mitchell et al. classify those with one attribute as 'latent', those with two attributes as 'expectant', and those with all three attributes, power, legitimacy and urgency, as 'definitive' stakeholders.

Those three attributes-power, legitimacy and urgency-are not static, but are increasingly dynamic. Although Government remains the most important HEI fundermaking it a definitive stakeholder-other stakeholders may move between latent and expectant status, and of course, stakeholders in different national and institutional contexts may enjoy different-context-dependent-salience. Likewise, the evolving social contract may lead some non-stakeholders to become legitimate stakeholders for the first time. The emergence of the knowledge economy has certainly changed the salience of business in some HEIs and university systems, adding the attribute 'urgency' to the legitimacy and power this stakeholder already possessed through business and industry representation on

Fig. 1 The relationships between stakeholders and university decision-making processes categorised by stakeholder salience

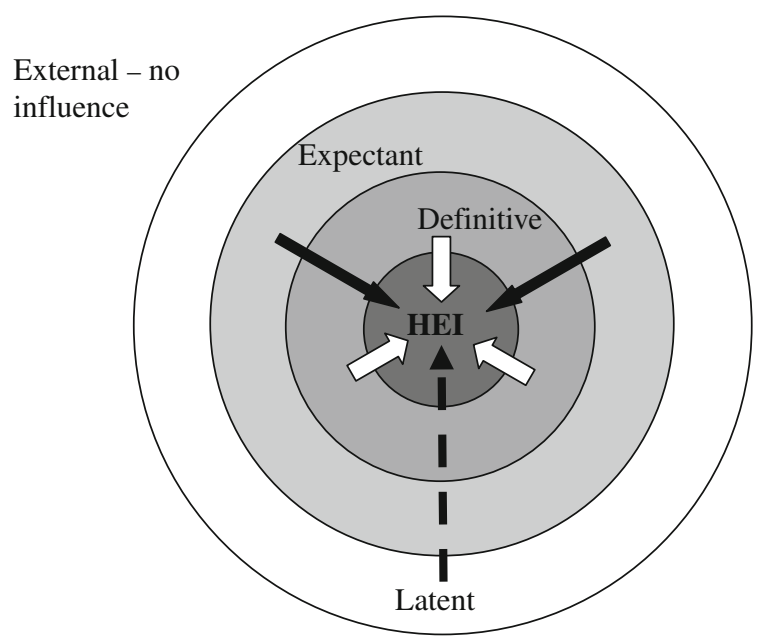


Boards of Trustees, faculty boards, accreditation committees, and professional associations. An additional dimension of complexity comes because higher education, in contrast to business, is far more fragmented in terms of its governance centres and decision-making processes (May 2007). In reality, not only central managers actively identify stakeholders, but various layers within the university also have their own stakeholders (Jongbloed et al. 2007). For the sake of simplicity, in this paper we begin from universities' external relationships including with HASS stakeholders.

\section{Stakeholder theory and valorisation in HASS}

Drawing on stakeholder theory, our hypothesis can be modified to:

HASS stakeholders have, because of their internal characteristics, failed to become salient stakeholders to universities, and universities have paid little attention to valorising their HASS research base (e.g. designing 'exploitability' into the work programmes of academics, research groups and faculties).

From a stakeholder perspective, stakeholders who might wish to exploit university HASS knowledge face implicit barriers to being regarded as salient by universities, reflecting the drivers initially outlined. Firstly, HASS stakeholder salience might be restricted by a discourse of academic capitalism which privileges benefits framed in monetized measurable forms. Secondly, HASS stakeholders might not be regarded as salient by groups seeking to encourage commercialisation. Thirdly, a lack of financial resources may inhibit universities' capacities to engage with HASS stakeholders' problems. These barriers may manifest themselves by undermining the three salience attributes we previously identified.

In power terms, HASS valorisation may receive less attention and support from central policy-makers and funding bodies because of its less tangible and measurable outputs. Stakeholders are often less high-profile and less well-configured than large researchintensive companies with their own scientists and laboratories. As Barnett (2003) notes,

The clients of the entrepreneurial university have to be able to afford its service: the entrepreneurial university is not inclined to put its capabilities at the service of just any client. A local community group might wish to take advantage, one evening, of the university's heated but underused rooms, but it will have to be able to afford the going rate. (p. 69)

Increasing HASS users' legitimacy appears superficially easiest to directly improve. In the 1970s, national governments across Europe and American compelled universities to open up their governance structures to students and social partners (Daalder and Shils 1982). Requiring increased HASS user participation in university decision-making in this way would give HASS users more direct influence. Yet in reality, university decision-making is shaped by a range of drivers, imposed by research and teaching funding agencies, internal research and teaching committees, evaluation and accreditation bodies and their strategic scientific collaborations (Scottish Government 2008). It is hard to see how simply giving HASS users more access to universities' decision-making procedures will address their relative powerlessness given the urgency and resources associated with other stakeholders' demands.

Increasing HASS users' urgency may also be achieved by declaring particular social issues of national significance and mandating universities to address those issues. The 
recent identification of such themes as terrorism and security, multi-culturalism, identity and democracy, to the decline of manufacturing, social cohesion and urban renewal (PPP 2008), suggests that this approach can be succeed. Given persistent underinvestment in HASS valorisation, it is unclear whether declarations alone will be sufficient to increase the regard paid by universities to HASS valorisation, implicitly at the expense of other more easily exploited disciplinary knowledge.

These three dimensions may not change in isolation and are influenced by broader contextual factors. Providing funding to HASS users to build capacity whilst making core funding dependent on valorisation and engagement can produce both internal and external university reconfigurations in which HASS users appear more salient to universities. Likewise, other fields or topics which become urgently important (such as sustainable energy) may crowd out universities' strategic interests and attention paid to HASS valorisation. To return to our initial research question, we ask four sub-questions:

- Who has taken decisions shaping universities' responses to HASS stakeholders?

- How are teaching and research funding criteria being shaped by policy interventions?

- Which stakeholders are involved-are they particular lead stakeholders, collective representatives or interested parties?

- How have universities responded in terms of redefining their institutional approach to social engagement?

\section{Policy interventions aiming to shift stakeholder salience}

To answer these questions, we review how three different policy instruments, adopted to improve universities' HASS valorisation, have affected stakeholders' salience. Because HASS valorisation has been relatively neglected in policy terms, our choice of instruments has been limited to examples where there is sufficient secondary material to begin to characterise those policies' impacts. We have chosen three policies that differ widely in terms of their programme size, their mechanism, and their applicability. In each case, we firstly consider the background framing of HASS valorisation within national policy discourses. We then consider how these types of instruments have affected the legitimacy, urgency and power of HASS users, and also within that, which types of HASS stakeholders have benefited. From that, we develop a bigger picture of how different valorisation instruments produce different institutional responses, and ultimately increase the voice of HASS users in the science governance system.

\section{The Community University Research Alliance (CURA) programme}

The background to the Canadian programme, "Community University Research Alliances" (CURAs), was a decade of relative underinvestment by the Canadian Federal government in higher education. From the mid-1990s, the Federal Government began intimating that a pre-condition for increased funding would be much greater focus on converting that funding into societal benefits. What emerged from a lengthy discussion period was an agreement for universities to treble their societal impacts over a 5 year period in response to a doubling of funding (McNaughton 2008). As part of the 2002 deal, universities were required to publish a five-yearly statement on their social impacts, and the CURAs formed an important component of their statement on the value of HASS research to Canada (see: AUCC 2002, 2005, 2008). 
The CURA programme is a large collaborative research investment programme funded by the Canadian Social Sciences and Humanities Research Council (SSHRC), providing long-term funding (up to 7 years) to "research alliances", partnerships of universities and community groups, to undertake a research programme with demonstrable community benefit. The alliance must encompass a range of partners, with significant structural influence over the lead body's research agenda. The CURA provides three stages of funding, capacity funding for writing a full bid, 5 years of core funding $(C \$ 1 \mathrm{~m} \mathrm{pa})$ and 2 years of completion funding. The universities responded enthusiastically to the proposals - in the first round, of 120 proposals, 15 were funded. This programme has been repeatedly evaluated and the evaluations have been relatively positive (inter alia SSHRC 2001; Kishchuk 2003; Barrington Research Group Inc (2004) cited in AUCC 2008).

The CURA programme has been relatively large scale in Canadian terms, particularly given the immediately preceding period of under-funding for universities. The scale of CURA funding proved attractive to universities, and in the competitive bidding process, bidders had to show how their core teaching and research activity would be shaped by the Alliance, and hence how the CURA would have a more general institutional impact. The CURAs funded a number of research centres which were free to generate other funding, including bidding for additional third stream and research funding. The CURAs have therefore become a meeting place for the engagement of universities with communities.

The communities which have been involved are those direct users of the research, which have tended to have a pre-existing link with the university research centre, and the CURA proposal has provided a means to formalize and strengthen those links. The programme provided community users with resources to engage in the bid-writing process, to ensure their influence from the outset. Community groups were also permitted to lead consortia, and in the first round, 4 of the 15 successful projects were led by community organizations, namely Kamloops Art Gallery, Research and Education for Solutions to Violence and Abuse, the Canadian Forum on Civil Justice, and Community Services Council of Newfoundland and Labrador (SSHRC 2001). The effect has been to favour partnerships where there are ongoing relationships between universities and other partners, which are primarily in the social sciences, with around $90 \%$ of all the funds being spent on social sciences and $10 \%$ on humanities.

What varied between universities was the degree to which the external stakeholders became central to the research governance of the universities involved in the partnerships. Evaluation found that the more central the stakeholders were in the steering bodies, the greater influence they exerted on the research, but that the degree of closeness they were permitted was determined by the involved institutions; some allowed their partners to be closely involved, whilst others did not (Kishchuk 2003). This did reflect the past linkages with community partners: the Saskatchewan Community University Institute of Social Research used the programme to formalize its relations with external partners, and publicly acknowledge the value of those links (CUISR 2004).

In characterising the intervention, we would highlight three points. Firstly, that even within a single HE system, a single instrument produced very divergent outcomes in terms of shifting stakeholder salience, which correlated to institutional enthusiasm for greater stakeholder involvement. Secondly, there remained a tendency within the system to favour more directly applicable research, prioritising social sciences over arts and humanities. Thirdly, the programme was large and directly changed university behaviour by paying them to change it, rather than achieving the much more difficult outcome of light touch influence. 
Scotland: a suitable cultural development strategy

Scotland's research and innovation system has only recently substantially diverged from that of England, following devolution in 1999, although it is has always had a separate higher education system. Prior to devolution, Scotland received a higher education funding council following the demise of the University Grants Committee in 1992. Since devolution, the Scottish Higher Education Funding Council (SHEFC, now part of the Scottish Funding Council, SFC) has become accountable to the Scottish Parliament, and so is extremely sensitive to distinctive Scottish Government policies and priorities. Following devolution, Scotland's Government chose to adopt a very distinctive science policy, Smart Successful Scotland (Scottish Executive 2001) which framed the value of science investment primarily in terms of its direct economic benefits (Benneworth 2004; Jones 2007). Since then, valorisation policies in Scotland, notably the Knowledge Transfer Grant, have focused on commercialisation (Benneworth 2007; Hodgson and Humphrey 2007).

Directly in response to Smart Successful Scotland, SHEFC increased its knowledge transfer expenditure. An early problem emerged around knowledge transfer in the arts, perceived as unprofessional and dependent on a few enthusiastic promoters for its impacts (inter alia SQW 2003; Hamilton and Sneddon 2004; Scottish Funding Council/Universities Scotland 2005). SHEFC therefore created a very small fund in 2005 ( $£ 0.6 \mathrm{~m})$ allocated between its 14 institutions, depending on their size, to part fund co-ordinator posts to work to improve the systematisation of HASS valorisation (SFC 2005, 2006). The only burden on the universities for these funds was a very short (2 page) application for which they received 1-year grants between $£ 20 \mathrm{k}$ and $£ 60 \mathrm{k}$ (SFC), a situation which persisted until 2008 (SFC 2008b).

Universities' responses to this policy were shaped by their almost unanimous opposition to attempts to allocate core grant on the basis of commercialisation metrics-including in HASS disciplines (SFC 2008a). The universities all developed strategies, but as all universities in Scotland already had a number of strategies, the question remains over the extent to which this strategy influenced university decision-making (KTIG 2008). A search of the 14 university websites in early 2008 revealed that none of the universities had a 'community office' promoting HASS valorisation. The majority of community offices were primarily focused on technological commercialisation or on lifelong learning and access, the two Scottish Government priorities. However, the process of drawing up the strategies at least made all the universities aware of their involvement with external stakeholders: all strategies were compelled to have a section on their existing good practice (see "Discussion and concluding remarks"), potentially creating pre-conditions for this strategy to become more central to the university interests (Miller 2009).

This policy approach created relatively few direct opportunities for external stakeholders to become more salient to the university (Segal Quince Wicksteed 2009); universities designed their own strategies, with no requirement to demonstrate claimed community involvement (Gani 2008). The key external stakeholders were the funding council themselves, and then to a lesser degree, the HASS community in Scotland more generally through organisations such as the Scottish Cultural Commission. These groups had a shared interest primarily in sustaining HASS funding levels, including that share provided by the funding council for arts infrastructure, and so ensuring HASS was seen as delivering 'benefits' was seen as being important in sustaining more general arts expenditure levels. Universities became a representative for the 'arts' community more generally in governmental discussions, and the strategy became important in positioning universities as important cultural actors. 
The instrument can be characterised as extremely light touch, allowing universities to decide their own strategies focused on making more systematic ad hoc activities already underway. This embodied the first step of an envisaged iterative model, informing senior managers about the potentially untapped resources within their research from which they might potentially benefit in the longer term. A review of the Knowledge Transfer Grant in Scotland, which funded the Cultural Engagement Strategy-noted that although the KTG had not radically altered knowledge transfer practice in Scotland, its one identifiable success was in cultural terms, where there had been significant awareness-raising within HEIs of their potential cultural impacts (SFC 2008a). Reflecting this success, the grant has been incorporated into the core grant at $£ 70,000$ for all 14 institutions, a doubling of funding (Miller 2009).

\section{Professionalising the Arts and Humanities Research Council}

The context for the UK situation is comparable to Canada: in 2001, a high profile doubling of government science funding was announced (DTI 2000). In contrast to Canada, in the UK, the Government initially accepted the argument that it would take a long time for these new investments to produce visible returns, and so initially did not demand immediate impact statements (Gummett 2009). However, since then, there has been growing pressure from central government on all UK science funders to demonstrate progress towards these longer term societal and economic impacts. In particular, there has been increasing emphasis on demonstrating the impact of research projects, with increasing space on research council applications and final reports given over to impact statements (RCUK 2006). The Arts and Humanities Research Council is the newest of the UK's research councils, created in 2005 from a predecessor board which was only responsible for allocating grant funding, whilst ARHC has a wider remit including research valorisation. AHRC itself regards valorisation as a key way to demonstrate its success as a research council, creating a substantial knowledge transfer fund comprising 7\% of 2006 budget (AHRC 2006).

AHRC sought to demonstrate its improving professionalisation, contributing to wider government interests in creating more societal added-value from research investments (cf. STSC 2006). AHRC's initial knowledge transfer focus was to address the culture of 'cheap research' in arts and humanities, funding research and valorisation on a full cost basis (RKTTG 2004a), exploring new models for HASS commercialisation (RKTTG 2005) and attempting to develop valorisation metrics (Metrics Expert Group 2006). Its initial focus took four main approaches, an innovation voucher scheme, collaborative studentships, collaborative research projects, and research exploitation schemes (AHRC 2006). Funds were made available through the standard research council route: individual academics (or teams) bid for funds, to valorise existing research projects which did not themselves have to have been AHRC-funded. The AHRC acknowledged many universities' already had well-developed commercialisation infrastructure geared towards accessing available funding sources. ${ }^{2}$ The AHRC therefore sought to exploit these existing infrastructures, and attract their attention by offering funding opportunities.

\footnotetext{
${ }^{2}$ We use the phrase business development manager to describe university employees whose primary function is helping to develop contacts between academics and external partners with the intention that this will bring some resource back into the university. In the case of HASS, BDMs might not actually be developing business, but might be negotiating collaborations and strategic partnerships with external cultural bodies such as museums and theatres.
} 
This approach gave a clear signal that all arts and humanities researchers should consider valorisation as a route to receive funds for discovery activities (RKTTG 2006). This could potentially have impacted significantly on universities' research strategies at the departmental/disciplinary level, and shaped the way that universities invest their recurrent arts and humanities income (related to research excellence) to increase overall expenditure through winning AHRC valorisation grants. Universities' responses were very promising; individual academics who submitted bids in the first round came with effectively identified social partners shaping the particular research activities. Although universities corporately may have been somewhat sceptical about HASS commercialisation, universities were even more sceptical about proposals to allocate HASS "third-stream" (knowledge exchange) funding via metrics, even whilst accepting the government's slogan "no metrics, no money" (RKTTG 2004a, b). ${ }^{3}$ Universities were corporately keen to demonstrate HASS valorisation to prevent the unilateral imposition of metrics. It is not clear whether these changes will lead to a larger shift in university behaviour, but they led to behavioural changes on at least two levels, the individual academics and within commercialisation offices.

AHRC investments were small but their intention appeared to be to sensitize universities to HASS valorisation opportunities, creating competition for knowledge transfer grants. However, the grants also clearly created new salience for other stakeholder classes, both large companies such as the BBC and city council archives who were able to collaborate with universities to win "Impact Awards" (collaborative research), but also for much smaller firms and community organisations to get involved through collaborative studentships and innovation voucher schemes. Universities required the active collaboration of a community stakeholder to access those funds. Such individuals did play a role in shaping their academic partners' research agendas. A final notable stakeholder was the UK Finance Ministry, the Treasury, seeking evidence concerning the effectiveness of their investments in the science base, and potentially receptive to persuasive evidence from AHRC.

The AHRC policy can be stylised as a high level attempt to change the culture of a university sector by changing the logic through which awards are made. However, this high level change has not had a whole-system effect, rather it was implemented by individual academics who chose to emphasise the impact of their research activity, and only indirectly changing HEI management practices and strategies. It is important to stress that this has been part of a wider emphasis of the "Impact" agenda in the UK, with recent signals that substantial amounts of core university funding will be allocated according to impact assessments (HEFCE 2008).

\section{Shaping university interest in HASS commercialisation}

Although the case studies are all very different in their scope and scale, there is some comparability between the three areas, summarized in Table 2, setting out the key attributes and impacts of policies in terms of stakeholder salience. Although the three policies had very different impacts, Table 2 highlights some interesting similarities between the policy areas, which assists in understanding the reality of HASS stakeholder relationships. The selective nature of policies affects the international transferability of our findings-

\footnotetext{
3 This is what happened-in HEIF 3, a $10 \%$ quantum was made available to universities to fund reach out activities that would be captured in narrow commercialisation metrics, pending the introduction of appropriate metrics for wider social impact. In failing to identify suitable metrics, the quantum was withdrawn, and a number of universities shifted away from seeking societal impact in their HEIF 4 bids.
} 
Table 2 The policy impacts on universities' HASS stakeholders in the three case studies

\begin{tabular}{|c|c|c|c|}
\hline & CURA & $\begin{array}{l}\text { Scotland's cultural } \\
\text { development strategy }\end{array}$ & $\begin{array}{l}\text { Knowledge transfer grants in } \\
\text { the arts }\end{array}$ \\
\hline $\begin{array}{l}\text { National } \\
\text { context } \\
\text { features }\end{array}$ & $\begin{array}{l}\text { Pressure to triple } \\
\text { universities' societal } \\
\text { contributions in return for } \\
\text { a doubling of funding }\end{array}$ & $\begin{array}{l}\text { Responding to a new set of } \\
\text { policy pressures from the } \\
\text { Scottish Government } \\
\text { focused strongly on using } \\
\text { universities to drive } \\
\text { economic development }\end{array}$ & $\begin{array}{l}\text { A doubling of science } \\
\text { funding in } 2000 \text { in return } \\
\text { for a promise to produce } \\
\text { huge downstream impacts; } \\
\text { increasing pressure after } \\
2005 \text { to show early results }\end{array}$ \\
\hline $\begin{array}{l}\text { Instrument } \\
\text { size }\end{array}$ & $\begin{array}{l}\text { Large scale, long-term } \\
\text { programme funding, eye- } \\
\text { catching and prestigious } \\
\text { for institutions }\end{array}$ & $\begin{array}{l}\text { Very small scale funding for } \\
\text { a new strategy and } \\
\text { someone to join up } \\
\text { university's cultural } \\
\text { contribution }\end{array}$ & $\begin{array}{l}\text { Standard project grant } \\
\text { funding levels for research } \\
\text { grants, knowledge transfer } \\
\text { partnerships }\end{array}$ \\
\hline $\begin{array}{l}\text { Scientific } \\
\text { articulation }\end{array}$ & $\begin{array}{l}\text { Creating a stream of research } \\
\text { (and possibly teaching) in } \\
\text { which community partners } \\
\text { have strong influence on } \\
\text { the chosen themes }\end{array}$ & $\begin{array}{l}\text { No direct influence over } \\
\text { academic decision-making } \\
\text { and research trajectories; } \\
\text { creating a boundary point } \\
\text { and community of interest }\end{array}$ & $\begin{array}{l}\text { Depends on academics to } \\
\text { choose for engagement. } \\
\text { Creates research projects } \\
\text { in which valorisation or } \\
\text { co-inquiry are integral }\end{array}$ \\
\hline $\begin{array}{l}\text { Resource } \\
\text { significance } \\
\text { to } \\
\text { universities }\end{array}$ & $\begin{array}{l}\text { Large: high-levels of long } \\
\text { term funding, plus a } \\
\text { mechanism to achieve their } \\
\text { commitment to } \\
\text { demonstrably treble their } \\
\text { research outputs }\end{array}$ & $\begin{array}{l}\text { Very low in terms of overall } \\
\text { budgets of individual } \\
\text { institutions } \\
\text { Opportunity to get someone } \\
\text { 'free' who may win new } \\
\text { resource streams }\end{array}$ & $\begin{array}{l}\text { Moderate; projects are } \\
\text { regular research council } \\
\text { size but large for } \\
\text { humanities } \\
\text { Creates a funding goal worth } \\
\text { universities chasing as } \\
\text { 'hard sciences' have long } \\
\text { had }\end{array}$ \\
\hline $\begin{array}{l}\text { Novel } \\
\text { stakeholders } \\
\text { involved }\end{array}$ & $\begin{array}{l}\text { Individual community } \\
\text { groups are the direct } \\
\text { beneficiaries, getting } \\
\text { research funding and } \\
\text { influence }\end{array}$ & $\begin{array}{l}\text { Cultural groups and users of } \\
\text { cultural facilities now have } \\
\text { a point of contact within } \\
\text { the university if they have } \\
\text { a query or request }\end{array}$ & $\begin{array}{l}\text { Makes any group with } \\
\text { sufficient resources in } \\
\text { humanities a potential co- } \\
\text { collaborator } \\
\text { AHRC need the schemes to } \\
\text { work to prove they are a } \\
\text { 'real' research council }\end{array}$ \\
\hline $\begin{array}{l}\text { Legitimacy } \\
\text { impacts }\end{array}$ & $\begin{array}{l}\text { Part of SSHRC/Federal } \\
\text { Government statement that } \\
\text { social engagement } \\
\text { important } \\
\text { Highlights role of } \\
\text { community stakeholders in } \\
\text { actively shaping teaching, } \\
\text { research }\end{array}$ & $\begin{array}{l}\text { Creates a point of contact in } \\
\text { the university for the } \\
\text { cultural sector; statement } \\
\text { that they have a voice to be } \\
\text { heard } \\
\text { Does not give the cultural } \\
\text { users the opportunity to } \\
\text { shape university decision- } \\
\text { making }\end{array}$ & $\begin{array}{l}\text { Clear signal that HASS are } \\
\text { valid research users and } \\
\text { provides access to new } \\
\text { research resources and } \\
\text { opportunities for research } \\
\text { in collaboration with } \\
\text { HASS users } \\
\text { Prestige of winning these } \\
\text { grants apparently high } \\
\text { because of high tulity }\end{array}$ \\
\hline $\begin{array}{l}\text { Urgency } \\
\text { impacts }\end{array}$ & $\begin{array}{l}\text { Relatively few impacts on } \\
\text { HASS users not directly } \\
\text { involved } \\
\text { The impact exercise creates } \\
\text { urgency to prove value and } \\
\text { helps universities to show } \\
\text { responsiveness, but not } \\
\text { improving HASS } \\
\text { representation generally }\end{array}$ & $\begin{array}{l}\text { Urgency driven by wider } \\
\text { HASS community in } \\
\text { Scotland, fear that losing } \\
\text { share of resources to the } \\
\text { commercial sectors } \\
\text { Universities also worry that } \\
\text { forced to accept HASS } \\
\text { metrics so engage with the } \\
\text { policy as an avoidance } \\
\text { strategy }\end{array}$ & $\begin{array}{l}\text { Limited urgency in the } \\
\text { approach-the idea is to } \\
\text { slowly build up idea of } \\
\text { humanities valorisation by } \\
\text { users and universities, not } \\
\text { to achieve it immediately }\end{array}$ \\
\hline
\end{tabular}


Table 2 continued

\begin{tabular}{|c|c|c|c|}
\hline & CURA & $\begin{array}{l}\text { Scotland's cultural } \\
\text { development strategy }\end{array}$ & $\begin{array}{l}\text { Knowledge transfer grants in } \\
\text { the arts }\end{array}$ \\
\hline Power impacts & $\begin{array}{l}\text { Gives particular stakeholders } \\
\text { potentially large power to } \\
\text { set the research agenda for } \\
\text { a university group and to } \\
\text { build its own network, } \\
\text { which may also benefit the } \\
\text { university }\end{array}$ & $\begin{array}{l}\text { Very minor; slight } \\
\text { rebalancing of power if } \\
\text { universities choose to let } \\
\text { stakeholders become } \\
\text { involved but no degree of } \\
\text { additional compulsion }\end{array}$ & $\begin{array}{l}\text { Hands quite a lot of power to } \\
\text { individual humanities users } \\
\text { to influence academics' } \\
\text { research opportunities by } \\
\text { giving them control over } \\
\text { access to these resources } \\
\text { Universities may respond to } \\
\text { this by being more } \\
\text { systematic about cultural } \\
\text { commercialisation activity }\end{array}$ \\
\hline $\begin{array}{l}\text { Overall } \\
\text { stakeholder } \\
\text { impacts }\end{array}$ & $\begin{array}{l}\text { Particular individual } \\
\text { community organisations } \\
\text { have become expectant } \\
\text { stakeholders in a number } \\
\text { of Canadian universities }\end{array}$ & $\begin{array}{l}\text { 'Culture' is a latent } \\
\text { stakeholder for Scottish } \\
\text { universities, something } \\
\text { that universities have to be } \\
\text { aware of and refer to }\end{array}$ & $\begin{array}{l}\text { Any cultural sector } \\
\text { organisation with sufficient } \\
\text { resource can become a } \\
\text { close stakeholder of } \\
\text { individual academics, but } \\
\text { the overall institutional } \\
\text { effect remains uncertain }\end{array}$ \\
\hline
\end{tabular}

they are all countries which have embraced academic capitalism as a key rationale for their public HE funding, and the policies analysed have been part of that moment of change. The lessons are arguably less applicable to regions and countries not undergoing that journey. However, both OECD and the European Commission are emphasising knowledge exchange as key university tasks and so it is likely that the lessons experienced in these cases will be experienced in other national systems as they deal with issues of valorisation (CEC 2003; OECD 2008). We now use the three case studies to address our four questions to develop a better understanding of HASS stakeholder relationships.

Our first question was who took decisions shaping universities' responses to HASS stakeholders. In all three cases, the decisions were taken by funding councils responsible for providing universities' teaching and research core grants. These funding councils were in all three contexts definitive university stakeholders, with the necessary capacity to compel universities to follow their decisions. However, these stakeholders were themselves strongly shaped by their own stakeholders' demands, notably finance ministries and the federal government, variously interested in justifying their budget increases, ensuring HASS remained well-funded by government, and proving their effectiveness. Conversely, funding councils were themselves dependent on universities' responses to their demands, and their need for successes to report to their funders positioned universities as salient stakeholders to funding councils. University influence was visible in such policies being light touch, avoiding metrics and funding formulae for HASS.

The second question was how teaching and research funding criteria were shaped by particular policy interventions. In no cases were universities' core grants made dependent on knowledge valorisation: instead, valorisation was made additional to HEIs' existing activities. Nevertheless, these various funding streams directly influenced universities' teaching and research activities, primarily by individual academic staff rather than senior managers. In particular, the CURAs and AHRC directly rewarded researchers willing to make valorisation more central to their own activities. The Scottish Cultural Engagement Strategy encouraged universities directly to change their behaviour, by creating a strategy against which university management could notionally be held accountable, although 
which in reality made managers more aware of their activities, and their impacts, which could be deployed to as legitimacy in their stakeholders' eyes.

The third question related to the kinds of stakeholder involved: significantly, in no cases were community representatives involved or mandated a greater say in universities' high level decision-making processes. Rather, two types of community stakeholder were involved, with two quite different rationales behind their involvement and influence. The first were "well configured lead stakeholders" who worked with universities to develop proprietorial systems to better engage with other community partners. These stakeholders were analogous to well-configured large companies with R\&D and contracting departments able to handle ongoing relationships. In some cases, because of the size of the emergent research proposals, such as the CURA, they were able to exert a significant influence on university decision-making (Kishchuk 2003).

The other type of community stakeholders were those-primarily evident in the AHRC approach-involved as humanities researchers learned to work with community groups. The AHRC attempted to create a norm that funding should be provided in return for valorisation via an agreed community user. These agreed users potentially had a much greater chance to influence universities' behaviours, as engagement—and community influence-become the norm. However, AHRC-led connections came primarily through academics who wanted to explore new research domains, who were offered new research resources in exchange for involving community partners; this gave the partners greater indirect influence over university research trajectories.

The fourth of our questions related to how universities responded by redefining their institutional approach to social engagement. Two features emerged across the three policy areas; the first was that research funders themselves were not sufficiently interested in societal impact to force universities to introduce social partners as central stakeholders through for example a voice on the university board. This left universities free to decide their approach to engagement internally, without having to consult community interests and representatives. Secondly, university responses could be characterised as seeking to access particular funding streams whilst preserving their institutional autonomy. Substantive changes emerged around confluences of interests within the university, between academics who seeking additional research streams, senior managers who wanted to develop their institutions in particular strategic directions, and business development managers who understood HASS valorisation.

These four answers together define a quite different set of relationships responsible for shaping university behaviour, between different stakeholders inside and outside of the university institutional boundaries, and also inside the boundaries of what could be considered 'government'. The determining relationships within this policy-making process appear to be primarily between government and university stakeholders. Policy-makers attempted encourage universities themselves to choose to build relationships with HASS users as proof of "impact", as a proxy for value for money and return on investment, giving added legitimacy. Against that, the power of the HASS stakeholders has only altered marginally in this process, and to some extent this has depended on voluntary, context-dependent and at best superficial changes made by universities (Fig. 2).

This model has implications for the development of policy models to improve universities' HASS valorisation. The first is the importance of university staff in changing universities' behaviour-although institutional-level changes are important, they are most sustainable as a response to academics demanding changes, alongside valorisation staff with suitable models and a degree of certainty that those changes will not be excessively disruptive. However, the rise of the discourse of academic capitalism has in some cases 


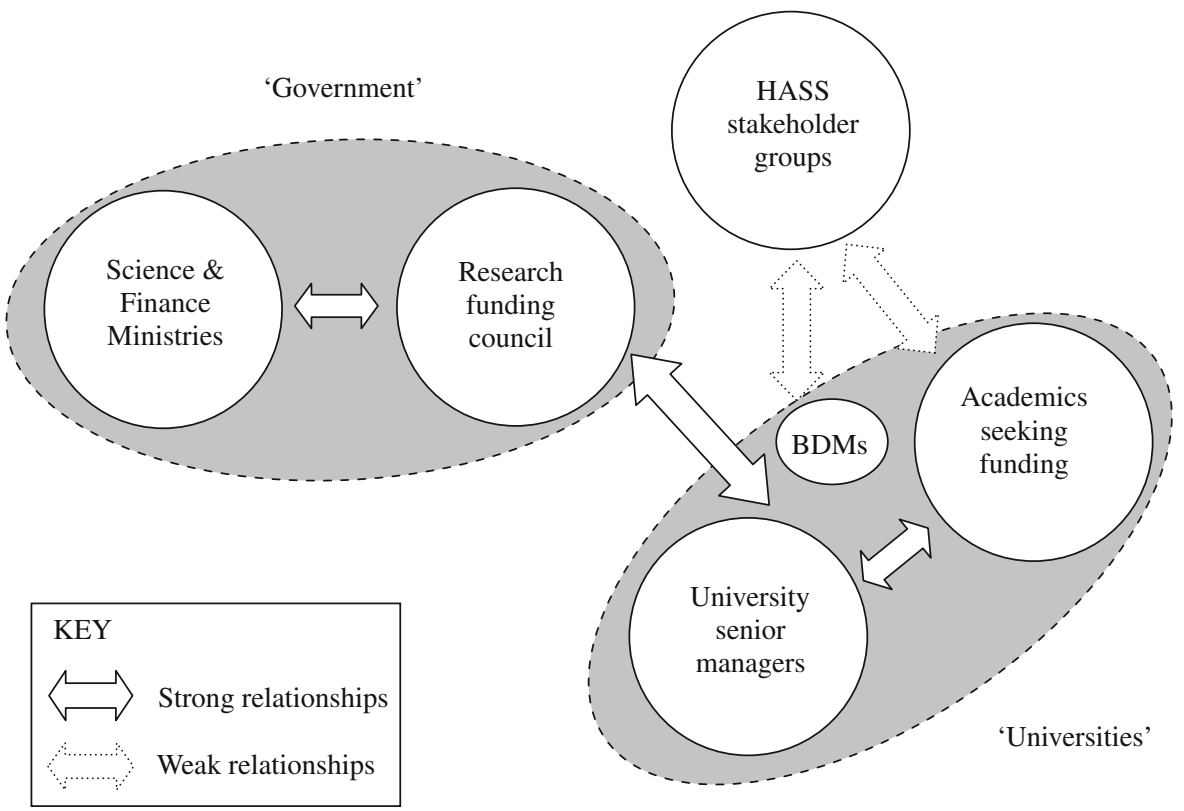

Fig. 2 Stakeholder relationships in changing attitudes to HASS valorisation

undermined engaged academics' freedom to continue working with particular partners in favour of central corporate relationships (May 2007). Likewise, if HASS valorisation becomes framed as the wrong kind of commercialisation then this may reduce universities' willingness to take the activity seriously.

The second is that relationships within government are important in determining how the policies develop. Ministries of Education and Science can be influenced by the demands of finance Ministries, not just in budgetary terms, but in setting the expected norms framing investment rationales, which shape the national 'variety' of academic capitalism. ${ }^{4}$ In the UK, AHRC was driven to develop a professionalization agenda not just because the science ministry encouraged it to do so, but because the science ministry was under general pressure to justify science budgets in terms of commercialisation outcomes. Pressure to commercialise knowledge was an unspoken norm framing all seven science councils, leading to unselfconscious concrete proposals to professionalise knowledge transfer activity in the 'humanities and arts'. This highlights the fact that there may be other regulatory and rule-setting stakeholders who indirectly influence the science system and the conditions under which HASS stakeholders become salient.

The final point is that any observable effects for HASS stakeholders were at best temporary-although salience was elevated for a period, once focus shifted away from the novelty of the instrument, there is little evidence of wider institutional changes which were themselves foundations for more general HASS stakeholder salience. No universities

\footnotetext{
${ }^{4}$ Hall and Soskice (2001) coin the phrase "varieties of capitalism" to refer to the particular national political-economic structures which define how the abstract notion of "capitalism" works in particular contexts. The same argument can be made with respect to academic capitalism, and that is what we refer to here, namely the way that particular global tendencies-commercialisation, massification, privatisationare implemented within particular national higher education systems.
} 
appointed community representatives to their boards, to better realise the potential highlighted through the particular policy activities. Nevertheless, some of these activities opened a 'window of opportunity' for more systemic change. If those opportunities could be consolidated in a more systemic manner, then it may be possible to realise some of HASS stakeholders' potential to be more salient to universities, and thereby improve the application of HASS to societal problems.

\section{Discussion and concluding remarks}

In this paper, we have been concerned with three fundamental questions:

1. Can a stakeholder approach conceptually illuminate why there are apparent problems with the valorisation of research in the humanities, arts and social sciences?

2. How do particular instruments work in practice when viewed from a stakeholder perspective?

3. What needs to be done differently in the light of these reflections in order to improve HASS valorisation in practice?

Our initial hypothesis was that HASS stakeholders have, because of their internal characteristics, failed to become salient stakeholders to universities, and therefore universities have paid little strategic attention to the valorisation of their HASS research base. Whilst there might be a lot of rhetoric around valorisation through engagement with community stakeholders, there is no evidence to suggest that community engagement has taken the step analogous to that taken by commercialisation. As Jongbloed et al. note "the growing chorus over the role of universities as economic engines has elevated the debate beyond rhetoric and into the realm of policy action" (2008, p. 313).

We observed temporary improvements in HASS stakeholders' salience, associated with short periods when universities appeared pressured or compelled by their main stakeholders. However, when the pressure receded, then stakeholders' interests drifted to the periphery of university concerns. How then to conceptualise these changes in terms of our stakeholder framework? The first remark is that it is not just stakeholders' direct salience to universities which is important—other leading societal/policy actors' perceptions are central in defining how salient universities regard HASS stakeholders.

This suggests the following process heuristic for how HASS stakeholders could become more salient. Some external bodies provided consistent pressure on universities to be more mindful of HASS stakeholders' concerns, helping anchor HASS stakeholders closer to the university. When a stakeholder set was temporarily brought closer into the university sphere of interest, other interventions consolidated the one-off, instrumental change into a more systemic shift, building that stakeholder into the university's governance networks. Rather than drifting away from the universities after the one-off intervention, network participation appeared to hold stakeholders 'closer' to the university (in terms of their salience) for a prolonged period of time. Stakeholders became part of a coalition collectively - if temporarily-important to the university. The case studies suggest at least four mechanisms which leading stakeholders deployed to change universities' attitudes to HASS stakeholders, including them in these salience coalitions:

1. providing long-term funding for projects involving community groups as significant partners in the research (CURA), 
2. providing the resources to professionalise university attempts to valorise HASS knowledges through business development managers and offices (AHRC),

3. encouraging universities to set valorisation as a strategic goal, and to open themselves up to being held to account to those missions (SFC), and

4. inviting HASS stakeholders to hold universities to account in terms of the overall institution impacts through valorisation activity.

However, this research also highlights the networked nature of salience, determined or framed by how other actors view HASS stakeholders. Salience is therefore an emergent property, defined through stakeholder relationships-not just between universities and HASS user groups-but also the wider networks and relationships which determine the societal valuation of university knowledge and valorisation activity. Figure 3 uses the same salience framework as in Fig. 1 to depict this dynamic network evolution. If more definitive stakeholders put pressure on universities to pay continued attention to the HASS stakeholders, then these weaker stakeholders may have a stronger and more durable position to respond to future valorisation opportunities.

Our main contribution in this paper is showing the value of using a stakeholder approach in higher education research, emphasising that university stakeholder relationships must be considered systematically, in the totality of the networks of relationships and connections in the HE system, and not merely bilaterally. This systemic nature has implications for the use of stakeholder theory in higher education research, for policy promoting valorisation, and for improving university valourisation performance. We conclude with a discussion of those areas.

The importance of systematic, multi-level stakeholder analysis

This paper asked whether stakeholder analysis was of value in understanding why HASS valourisation did not proceed smoothly. What the case studies have suggested is that a stakeholder conceptualisation is indeed useful in understanding how universities take decisions, and can explain HASS valorisation's low prioritisation within higher education. However, the mechanism that we have explored—'changing salience'—was too simplistic: the case studies suggested that it is not possible to simply increase stakeholders' salience for universities. Rather, their salience is constructed within wider networks of relationships. Analyses which are interested in understanding stakeholder salience as an explanation of changing university behaviour must therefore consider the wider systemic relationships and networks within which salience is defined.

The system can be represented as containing a number of nested levels. At the macrolevel, there are national systems, the variant of academic capitalism adopted, framing the hierarchy of universities' external stakeholders. At the meso-level, there are relationships between key government actors such as funding councils and the university sector, in which the HE system is funded in return for the delivery of outputs. At the micro-level, there are universities and agencies in specific contexts working to exploit the HASS knowledge base in tandem with community stakeholders. It is important in undertaking stakeholder research into HE to be clear which system level is being talked about. However, it is also important to respect the relationships between the levels of multi-level systems, and accept that norms and varieties of academic capitalism (higher levels) are constructed out of policy decisions and successful outcomes at the micro-level, and do not simply determine them (Geels 2002). 


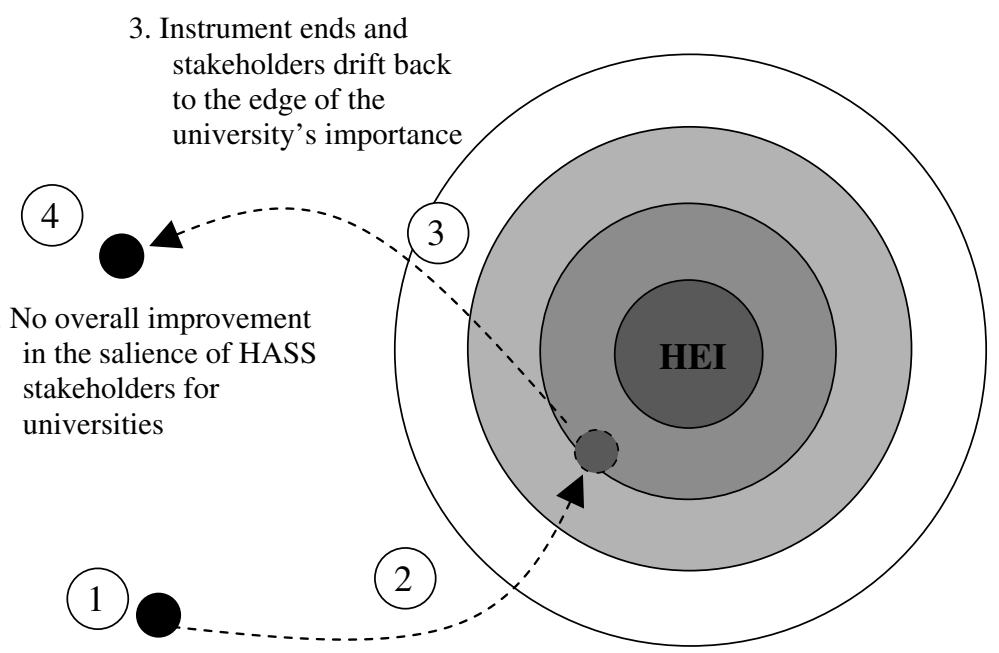

1. Lack of salience of HASS stakeholders stimulates a new valourisation policy
2. Policy instrument temporarily increases HASS stakeholder salience

3. Other stakeholders demand that the university continues to prioritise HASS

4. HASS stakeholders end up anchored as a more salient stakeholder for the university

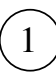

1. Lack of salience of HASS stakeholders stimulates a new valourisation policy

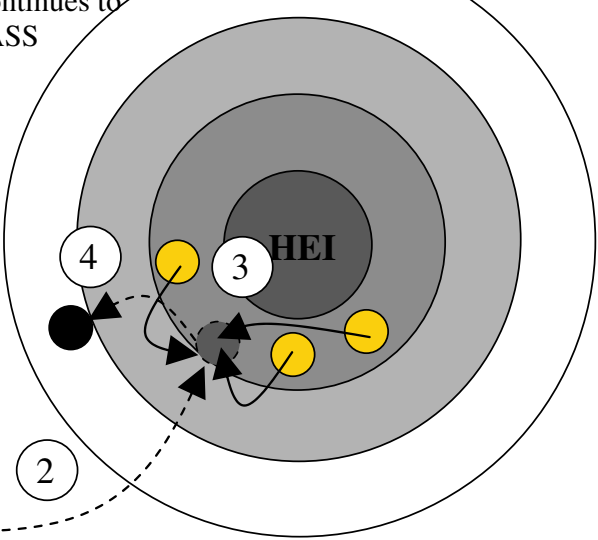

2. Policy instrument temporarily increases HASS stakeholder salience

Fig. 3 Short-term policies and longer term shifts in HASS valourisation

Systemic policies for HASS valorisation

This systemic and multi-level construction of stakeholder salience has important policy implications. The policies we explored aimed to directly increase salience primarily at the micro-scale, but when the interventions ended, then the macro-/meso- systemic tendencies 
reasserted themselves with the result that HASS stakeholders drifted to the periphery of university interests. If salience is constructed within higher education relationship systems, then macro- and meso-level changes are necessary to influence individual universities' (micro-scale) decisions to prioritise HASS valourisation. We identified four drivers at the micro- and meso-scales, which could initiate changes, and potentially concatenate into macro-level changes, namely university strategic changes, professionalization of HASS, making core research and teaching grants dependent on valorisation, and allowing HASS stakeholders to hold universities to account for their commitments. In Scotland, there some evidence of "upscaling", this concatenation-the fact that universities have found writing strategies (micro-) a useful process has led the funding council to frame cultural engagement as a core university activity. What we cannot demonstrate systematically are pathways for upscaling, how individual small policies can have larger impacts on relationships and policy styles of HE systems.

Taking a more systematic, multi-level approach to HASS valorisation as outlined above involves a significant effort from a wide range of the actors identified above, understanding and influencing the activities listed above, including universities, funding councils, sectoral organisations, community groups, academics, BDMs, BDM sectoral organisations, finance ministries, and science and education ministries. Platforms or intermediary organisation may well be necessary to bring these partners together, rebalancing universities' priorities towards valourisation, and promote a range of policies. This multi-scalarity of valorisation systems - building changes at the level of the discourse alongside sequences of small policy experiments - highlights the magnitude of the endeavour, perhaps also explaining why progress to date has been so patchy. It is important to stress that shifting towards a system which favours HASS valorisation is not 'all-or-nothing'. Systems evolve slowly: micro-changes may upscale, leading to more fundamental shifts in the particular flavour of academic capitalism. Likewise, unintended shifts in macro-governance systems and mesopolicy systems may reframe dominant discourses, unintentionally shifting particular groups' salience to universities.

\section{Internal university shifts}

The final element is the centrality of the university qua institution to these arrangements. Multi-level approaches in general always risk making actors seem powerless in the face of large and unchallengeable structures and systems (Law 2004). The context for this paper is that universities cannot simply change their priorities unilaterally, but such changes happen within the context of universities' shifting relationships with other key stakeholders within national HE systems. But we have also found that universities themselves partly determine those relationships, both through their bilateral relationships with other system actors, and also through branch organisations such as Universities UK, the Association of Universities and Colleges of Canada or the (Dutch) VSNU. If HASS stakeholders' salience is constructed through university relationships with other actors, then those other actors will in turn be influenced by what universities (and branch organisations) say about the potential for HASS valorisation.

Indeed, the message emerging here is that the university itself must start to speak for these community stakeholders, and encourage government and other actors to imbue them with legitimacy, resources and urgency. Once that is done, the experience with entrepreneurial universities and business stakeholders (e.g. Clark 1998) suggests that universities themselves will be willing to take HASS knowledge users much more seriously as research users, partners and ultimately stakeholders. This could potentially create a far more fruitful 
environment for the valorisation of HASS research, and help universities further to fulfil their promise to enrichen their host societies.

Acknowledgments This paper was prepared with the assistance of funding from a Visiting Research Fellowship at the Institute of Governance Studies at the University of Twente in the Netherlands, and as part of a Research Councils UK Academic Fellowship at Newcastle University. Earlier versions of this paper have been presented at a departmental seminar at the Center for Higher Education Policy Studies at the University of Twente, August 2007, and at the Consortium of Higher Education Research conference, September 2008. This paper also reports findings gathered within the framework of the research project "Universities and community engagement", funded by the UK Economic and Social Research Council along with the four UK funding councils. We would like to thank two anonymous referees for their comments which have been invaluable in revising the paper, and to the journal editor for their guidance through the review process. Any errors or omissions remain the responsibility of the authors.

Open Access This article is distributed under the terms of the Creative Commons Attribution Noncommercial License which permits any noncommercial use, distribution, and reproduction in any medium, provided the original author(s) and source are credited.

\section{References}

Ackoff, R. L. (1981). Creating the corporate future. Chichester: Wiley.

AHRC. (2006). AHRC's knowledge transfer plan. Swindon: AHRC. Available online at: http://www.ahrc. ac.uk/images/4_97014.pdf.

Allen, M. (1988). The goals of universities. Milton Keynes: Society for Research into Higher Education/ Open University Press.

AUCC. (2002). Trends in higher education. Ottowa: Association of Universities and Colleges of Canada.

AUCC. (2005). Momentum: The 2005 report on university research and knowledge transfer. Ottowa: Association of Universities and Colleges of Canada.

AUCC. (2008). Momentum: The 2008 report on university research and knowledge transfer. Ottowa: Association of Universities and Colleges of Canada.

AWT. (2007). Alfa en Gamma stralen-Valorisatiebeleid voor de Alfa-en Gammawetenschappen. Den Haag: Adviesraad voor het Wetenschaps-en Innovatiebeleid.

Barnett, R. (Ed.). (1990). The idea of higher education. Buckingham: Society for Research into Higher Education; Open University Press.

Barnett, R. (2000). Realising a compact for higher education. In K. Moti Gokulsing \& C. DaCosta (Eds.), A compact for higher education. Ashgate: Aldershot.

Barnett, R. (2003). Beyond all reason: Living with ideology in the university. Buckingham: Society for Research into Higher Education; Open University Press.

Barrington Research Group Inc. (2004). Community-University Research Alliances (CURA) program: Analysis of data contained within the milestone and year 1 reports, prepared for the Social Sciences and Humanities Research Council.

Baumunt, Z. (1997). Universities: old, new and different. In A. Smith \& F. Webster (Eds.), The post-modern university? Contested visions of higher education in society. Milton Keynes: Open University Press.

Benneworth, P. (2004). Regional science policy \& instruments: An overview of British developments. In Report to the "Strategy for Success" scrutiny panel. Newcastle: CURDS.

Benneworth, P. S. (2007). Leading innovation: Building effective regional coalitions for innovation. London: National Endowment for Science, Technology and the Arts.

Bridgman, T., \& Wilmott, H. (2007). Academics in the 'knowledge economy': From expert to intellectual? In A. Harding, A. Scott, S. Laske, \& C. Burtscher (Eds.), Bright satanic mills: universities, regional development and the knowledge economy. Ashgate: Aldershot.

Bryson, J. (2000). Spreading the message: Management consultants and the shaping of economic geographies in time and space. In J. R. Bryson, P. W. Daniels, N. Henry, \& J. Pollard (Eds.), Knowledge, space, economy. London: Routledge.

Burrows, J. (1999). Going beyond labels: A framework for profiling institutional stakeholders. Contemporary Education, 70(4), 5-10.

Clark, B. (1998). Creating entrepreneurial universities. Organizational pathways of transformation. Oxford: Pergamon. 
Cohen, M., \& March, J. (1974). Leadership and ambiguity: The American College President. New York, NY: McGraw Hill.

Commission of the European Communities. (2003). The role of the universities in the Europe of knowledge $\operatorname{COM}(2003) 58$ final.

Community-University Institute for Social Research. (2004). Building community together: CommunityUniversity Institute for Social Research: present and future. Saskatoon: University of Saskatchewan.

Daalder, H., \& Shils, E. (1982). Universities, politicians and bureaucrats: Europe and the United States. Cambridge: Cambridge University Press.

Department of Trade and Industry. (2000). Excellence and opportunity—A science and technology policy for the 21st century. London: The Stationary Office.

Ernste, H. (2007). The international network university of the future and its local and regional impacts. In A. Harding, A. Scott, S. Laske, \& C. Burtscher (Eds.), Bright satanic mills: Universities, regional development and the knowledge economy. Ashgate: Aldershot.

Freeman, R. E. (1984). Strategic management: A stakeholder approach. Boston: Pitman.

Gani, D. (2008). Knowledge exchange in Scotland: what are we learning. Paper presented to Association of University Research and Industrial Liaison Conference, Glasgow, Scotland, 10th October 2008.

Geels, F. W. (2002). Technological transitions as evolutionary reconfiguration processes: A multi-level perspective and a case-study. Research Policy, 31(8-9), 1257-1274.

Geiger, R. L. (1993). Research and relevant knowledge. Oxford: Oxford University Press.

Greenwood, D. (2007). Who are the real problem-owners. In A. Harding, A. Scott, S. Laske, \& C. Burtscher (Eds.), Bright satanic mills: Universities, regional development and the knowledge economy. Ashgate: Aldershot.

Gummett, P. (2009). Effective policies for university/community engagement. Paper presented to excellence in engagement: Policies and practices for university-community engagement, KITE-ESRC Symposium, Newcastle-upon-Tyne, 22nd June 2009.

Hall, P., \& Soskice, D. (2001). Varieties of capitalism: The institutional foundations of comparative advantage. Oxford, UK: Oxford University Press.

Hamilton, C., \& Sneddon, N. (2004). Scoping study on cultural engagement and knowledge transfer in Scottish universities. Edinburgh: SHEFC.

HEFCE. (2007). "Funding higher education in England: How HEFCE allocates its funds", HEFCE circular 20/2007. Swindon: Higher Education Funding Council for England.

HEFCE. (2008). User-valued research in the Research Excellence Framework (REF): Background paper. In HEFCE and UniversitiesUK workshop. London, 31st October 2008.

Hodgson, C., \& Humphrey, L. (2007). "Regional leadership in innovation policy: Scotland case-study" NESTA research project case study report. Newcastle: IPP.

Jawahar, I. M., \& McLaughlin, G. L. (2001). Toward a descriptive stakeholder theory: An organizational life cycle approach. Academy of Management Review, 26(3), 397-414.

Jones, R. (2007). New forms of research and knowledge production in Scotland: The discourse of knowledge transfer. Discourse, 28(1), 101-120.

Jongbloed, B., Enders, J., \& Salerno, C. (2007). Higher education and its communities: Interconnections, interdependencies and a research agenda. Higher Education, 56(3), 303-324.

Jongbloed, B., \& Goedegebuure, L. (2001). From the entrepreneurial university to the Stakeholder University. In Proceedings of the international congress on "Universities and regional development in the Knowledge Society”. Universitat Politècnica de Catalunya Barcelona, 12-14 November 2001.

Kishchuk, N. (2003). Performance report: Phase 1 of the community university research alliances programme. Ottowa: SSHRC (Canada).

Knowledge Transfer and Innovation Group. (2008). "Minutes of joint meeting of KTIG and Scottish funding council research and knowledge transfer committee", RKTC-KTIG/O8Min1. Edinburgh: SFC.

Law, J. (2004). And if the global were small and noncoherent? Method, complexity, and the baroque. Environment and Planning D: Society and Space, 22(1), 13-26.

Marginson, S. (2007). University mission and identity for a post post-public era. Higher Education Research and Development, 26(1), 117-131.

May, T. (2007). Regulation, engagement and academic production. In A. Harding, A. Scott, S. Laske, \& C. Burtscher (Eds.), Bright satanic mills: Universities, regional development and the knowledge economy. Ashgate: Aldershot.

McNaughton, T. (2008). Technology commercialisation and universities in Canada. In OECD (Ed.), Entrepreneurship and higher education. Organisation for Economic Co-operation and Development: Paris.

Metrics Expert Group. (2006). Use of research metrics in the arts and humanities. A report to the Arts and Humanities Research Council and the Higher Education Funding Council for England. 
Miller, A. (2009). Contemporaneous note of authors' telephone conversation. 9th July 2009.

Mitchell, R. K., Agle, B. R., \& Wood, D. J. (1997). Toward a theory of stakeholder identification and salience: Defining the principle of who and what really counts. Academy of Management Review, 22(4), 853-886.

NCIHE. (1997). Higher education in the learning society (The 'Dearing Committee' report). London: National Committee of Inquiry on Higher Education.

Neave, G. (2006). Redefining the social contract. Higher Education Policy, 19, 269-286.

OECD. (2007). Higher education and regions: globally competitive, regionally engaged. Paris: Organisation for Economic Co-operation and Development/Institutional Management of Higher Education.

OECD. (2008). Entrepreneurship and higher education. Paris: Organisation for Economic Co-operation and Development.

PPP. (2008). Engaging higher education in the societal challenges of the 21st century. San Jose, CA: National Center for Public Policy and Higher Education.

RCUK. (2006). Adding value: How the Research Councils benefit the economy. Swindon: RCUK. Available online at http://www.rcuk.ac.uk/cmsweb/downloads/rcuk/publications/addingvalue.pdf.

Reed, H., \& Stanley, K. (2005). Co-operative social enterprise and its potential in public service delivery. London: Institute for Public Policy Research.

RKTTG. (2004a). "Critical analysis of the evidence base” paper to the Research and Knowledge Transfer Task Group, 24th August 2004. London: Creative Industries/Higher Education Forum.

RKTTG. (2004b). "Background" paper to the research and knowledge transfer task group, 24th August 2004. London: Creative Industries/Higher Education Forum.

RKTTG. (2005). Unweaving the rainbow. Paper to the Research and Knowledge Transfer Task Group AHRC/TG/09/05/1, 30th Sept 2005.

RKTTG. (2006). In search of innovation. Paper to the Research and Knowledge Transfer Task Group AHRC/TG/04/06/2, 28th April 2006.

Rothblatt, S. (1997). The modern university and its discontents. Cambridge: Cambridge University Press.

Scottish Executive. (2001). A smart successful Scotland. In A science strategy for Scotland. Edinburgh: Scottish Executive.

Scottish Funding Council. (2005). "Cultural engagement: An imperative for Scotland's higher education institutions" SFC consultation document. Edinburgh: SFC.

Scottish Funding Council. (2006). “Knowledge transfer grant: cultural engagement strategy” SFC circular 59/2006. Edinburgh: SFC.

Scottish Funding Council. (2008a). "Evaluation of the knowledge transfer grant" Scottish funding council and knowledge transfer committee Paper 09/12 Item 7. Edinburgh: SFC.

Scottish Funding Council. (2008b). "Knowledge transfer grant: collection of activity data from HEIs” SFC Circular SFC/51/2008. Edinburgh: SFC.

Scottish Funding Council/Universities Scotland. (2005). Knowledge transfer from Scotland's Higher Education Institutions: Progress and prospects. Edinburgh: SFC/US.

Scottish Government. (2008). Joint future thinking taskforce on universities-Stakeholder summit at glasgow Caledonian University on 20 August 2008-Main points. Edinburgh: Scottish Government.

SEC. (2003). There's more to enterprise than you think: a guide to social enterprise. London: Social Enterprise Coalition. Available on-line at: http://www.socialenterprise.org.uk/documents/guide.pdf.

Segal Quince Wicksteed. (2003). Knowledge transfer in Scotland: a scoping study. Report for SHEFC: Edinburgh, Scotland: SHEFC. Available on-line at: http://www.scotland.gov.uk/Resource/Doc/82254/ 0065034.pdf.

Segal Quince Wicksteed. (2009). Evaluation of the knowledge transfer grant. Report for Scottish Funding Council: Edinburgh, Scotland: SFC (available by request).

Slaughter, S., \& Leslie, L. (1997). Academic capitalism: Politics. Policies and the Entrepreneurial University, Baltimore, MD: Johns Hopkins University.

Slaughter, S., \& Leslie, L. (2001). Expanding and elaborating the concept of academic capitalism. Organization, 8(2), 154-161.

Spaapen, J., Dijstelbloem, H., \& Warmelink, F. (2007). Evaluating research in context. A method for comprehensive assessment. The Hague: Consultative Committee of Sector Councils for Research and Development (COS), the Netherlands.

SSHRC. (2001). Community University Research Alliance Backgrounder, Ottowa: SSHRC (Canada). Available on-line at: http://www.sshrc.ca/web/apply/background/cura2001_backgrounder_e.pdf.

STSC. (2006). "Arts \& Humanities Research Council memorandum: Research Council support for knowledge transfer", memorandum published in Research Council support for knowledge transfer, report of the Commons Science and Technology Select Committee, Vol II: evidence, London: HMSO, pp. 62-66. 